\title{
Evidence of paleo-cold seep activity from the Bay of Bengal, offshore India
}

\author{
A. Mazumdar, P. Dewangan, H. M. Joäo, A. Peketi, V. R. Khosla, M. Kocherla, \\ F. K. Badesab, R. K. Joshi, P. Roxanne, P. B. Ramamurty, and S. M. Karisiddaiah \\ National Institute of Oceanography, Dona Paula, Goa 403004, India (maninda@nio.org)
}

D. J. Patil and A. M. Dayal

National Geophysical Research Institute, Uppal Road, Hyderabad 500007, India

\author{
T. Ramprasad \\ National Institute of Oceanography, Dona Paula, Goa 403004, India
}

\section{J. Hawkesworth and R. Avanzinelli \\ Department of Earth Sciences, Faculty of Science, University of Bristol, Wills Memorial Building, Bristol BS8 1RJ, UK}

[1] We report evidence of paleo-cold seep associated activities, preserved in methane-derived carbonates in association with chemosynthetic clams (Calyptogena sp.) from a sediment core in the Krishna-Godavari basin, Bay of Bengal. Visual observations and calculations based on high-resolution wet bulk density profile of a core collected on board R/V Marion Dufresne (May 2007) show zones of sharp increase in carbonate content (10-55 vol \%) within 16-20 meters below seafloor (mbsf). The presence of Calyptogena clam shells, chimneys, shell breccias with high $\mathrm{Mg}$ calcite cement, and pyrite within this zone suggest seepage of methane and sulfide-bearing fluid to the seafloor in the past. Highly depleted carbon isotopic values $\left(\delta^{13} \mathrm{C}\right.$ ranges from -41 to $-52 \%$ VPDB) from these carbonates indicate carbon derived via anaerobic oxidation of methane. Extrapolated mean calendar age ( $\sim 58.7$ ka B.P.) of the clastic sediments at a depth of 16 mbsf is close to the upper limit of the U-Th based depositional age (46.2 \pm 3.7 and $53.0 \pm$ $1.6 \mathrm{ka}$ ) of authigenic carbonates sampled from this level, thereby constraining the younger age limit of the carbonate deposition/methane expulsion events. The observed carbonate deposition might have resulted from the flow of methane-enriched fluids through the fracture network formed because of shale diapirism.

Components: 8456 words, 8 figures, 2 tables.

Keywords: methane hydrate; cold seep; authigenic carbonate; Bay of Bengal; AMO; chemosynthetic community.

Index Terms: 1099 Geochemistry: General or miscellaneous; 3004 Marine Geology and Geophysics: Gas and hydrate systems; 3022 Marine Geology and Geophysics: Marine sediments: processes and transport.

Received 24 November 2008; Revised 10 April 2009; Accepted 29 April 2009; Published 12 June 2009.

Mazumdar, A., et al. (2009), Evidence of paleo-cold seep activity from the Bay of Bengal, offshore India, Geochem. Geophys. Geosyst., 10, Q06005, doi:10.1029/2008GC002337. 


\section{Introduction}

[2] Marine cold seep associated authigenic carbonates are known from modern and past geological records [Hovland et al., 1987; Kulm and Suess, 1990; Greinert et al., 2001; Campbell et al., 2002; Mazzini et al., 2004; Campbell, 2006; Naehr et al., 2007; Bayon et al., 2007; Pierre and Fouquet, 2007; Kazutaka and Jenkins, 2007; Han et al., 2008]. Cold seeps are characterized by expulsion of fluid enriched in methane, hydrogen sulfide, and bicarbonate from the seafloor that results in the precipitation of calcium carbonates and pyrite at or below the sediment-water interface, often associated with a proliferation of chemosynthetic communities [Levin, 2005].

[3] Cold seeps may also be associated with methane hydrate deposits [Sassen et al., 1998; Suess et al., 2001; Leon et al., 2007; Sahling et al., 2008]. Methane hydrate, a crystalline, ice-like form of methane and water (molar ratio 1:6) exists within the marine sediments at suitable temperature-pressure conditions [Kvenvolden, 1993; Sloan, 1998; Kvenvolden and Lorenson, 2001; Milkov et al., 2003; Hovland, 2005].

[4] In the Krishna-Godavari (K-G) Basin (Bay of Bengal), seismic data show the regional presence of gas hydrates manifested in the form of a bottom simulating reflector (BSR) [Ramana et al., 2007; Sain and Gupta, 2008; Collett et al., 2008]. BSRs represent a phase boundary where low-velocity gas-charged sediments occur below the hydrate stability zone [Hyndman and Spence, 1992; Singh et al., 1993; Holbrook et al., 1996]. Recent drilling and logging activities on board JOIDES Resolution in the Indian margin under the aegis of Indian National Gas Hydrate Program (NGHP) [Sethi and Ahmad, 2006; Collett et al., 2008; T. S. Collett et al., Indian Continental margin gas hydrate prospects: Results of the Indian National Gas Hydrate Program (NGHP), Expedition 01, paper presented at 6th International Conference on Gas Hydrates, Chevron Energy Technology Company, Vancouver, British Columbia, Canada, 2008; M. Kastner et al., Gas hydrate in three Indian Ocean regions: A comparative study of occurrence and subsurface hydrology, paper presented at 6th International Conference on Gas Hydrates, Chevron Energy Technology Company, Vancouver, British Columbia, Canada, 2008] have confirmed the existence of massive gas hydrate deposits in the K-G Basin. Possible fossil chemosynthetic communities composed of mollusk shells with some encrusted by carbonate worm tube (Serpula sp.) were reported by
Collett et al. [2008] from NGHP-01-10 and NGHP01-12 coring sites. Concentrations of authigenic carbonate nodules varying in size from a few millimeters to over $5 \mathrm{~cm}$ were observed with fossil assemblages. In this paper we have carried out comprehensive investigation of the geological and geochemical records of cold-seep-related processes revealed in a sediment core located above a mud mound and a well-defined BSR. Our studied core is located close to the NGHP-01-10D. We also constrain the timing of the formation of methane derived authigenic carbonates and occurrence of a chemosynthetic community.

\section{Geological Setting and Study Area}

[5] The K-G basin is a pericratonic rift basin located in the middle of the eastern continental margin of India [Rao, 2001; Bastia, 2007]. It is one of the proven petroliferous basins of India [Bastia, 2007]. The eastern continental margin of India came into existence because of the breakup of eastern Gondwanaland when India drifted away from East Antarctica [Powell et al., 1988]. The location of the K-G basin coincides with the triple junction of the diverging Indian, Australian and Antarctic plates [Rao, 1993]. The separation of Peninsular India from Antarctica and Australia initiated around $133 \mathrm{Ma}$ ago across the present $\mathrm{NE}-\mathrm{SW}$ trend of the eastern continental margin [Ramana et al., 1994, 2001]. The maximum sediment thickness in the K-G basin reaches as much as $8000 \mathrm{~m}$ [Prabhakar and Zutshi, 1993], and the Godavari and Krishna rivers supply the bulk of the detrital sediments to the basin. The smectite-bearing Godavari Clay Formation constitutes the HolocenePleistocene deposit of the K-G basin [Rao, 2001].

[6] The study area lies within the continental slope region of the K-G basin (Figure 1). A 29.9 m long core was collected on board R/V Marian Dufresne (MD-161: May 2007) using a Giant Calypso piston corer at a water depth of $1033 \mathrm{~m}$ (latitude = $15^{\circ} 51.8624^{\prime} \mathrm{N}$ and longitude $=81^{\circ} 50.0692^{\prime} \mathrm{E}$ ). The core location was selected on the basis of published multichannel seismic data [Ramana et al., 2007; Sain and Gupta, 2008; Collett et al., 2008] and subbottom profiler (SBP) data (this work).

\section{Methodology}

\subsection{Geophysical and Geological Methods}

[7] Subbottom profiler data was collected using a Seafalcon 11 echosounder. This system produces 


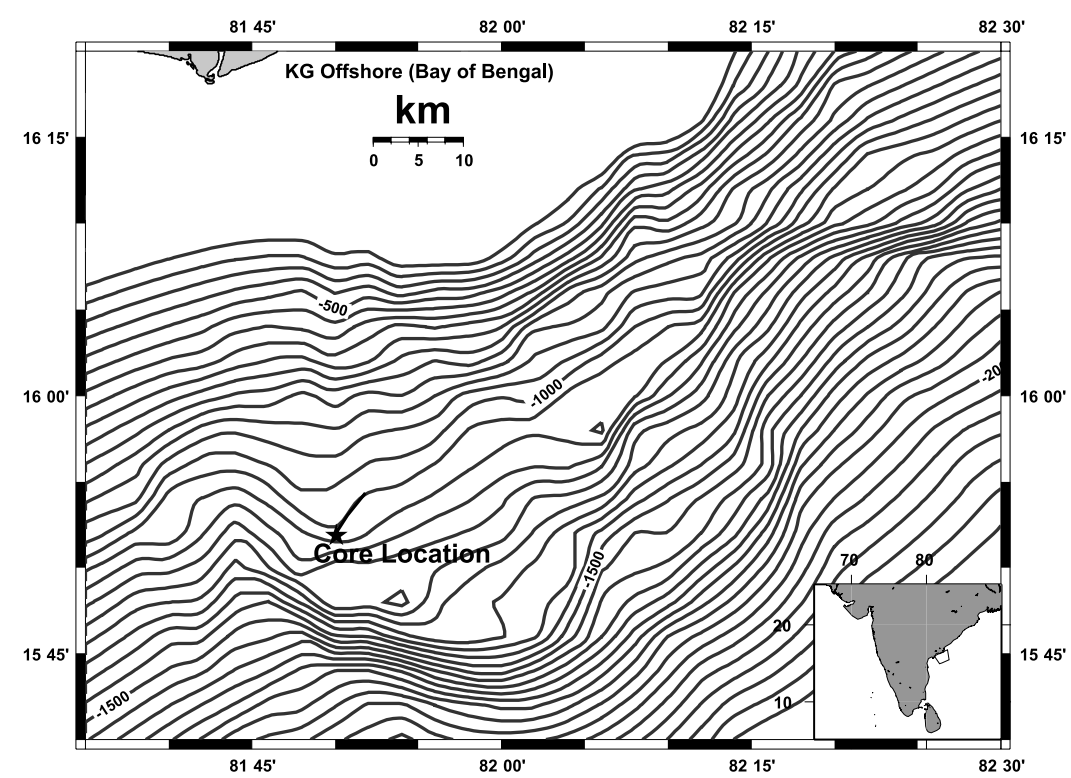

Figure 1. Study area in the Krishna-Godavari basin, Bay of Bengal. Core location is shown by a star. The solid line through core location represents the SBP track. Contour interval is $50 \mathrm{~m}$.

high-resolution, zero-offset acoustic sections of the subsurface as a function of the geographical position of the ship. One of the main features of this profiler is the use of a large, dedicated transmission array, large bandwidth signal, and long size multibeam reception array to create a high-acoustic level signal and a very narrow beam width. Whereas classical profiler's beam widths are usually $20^{\circ}$ to $30^{\circ}$, the Seafalcon 11 echosounder produces a $7.4^{\circ}$ beam width. This feature minimizes the interferences between different objects located in the illuminated scene and improves the horizontal resolution of the seismic data. The central frequency used in this system is $3.75 \mathrm{KHz}$. The data were exported to seismic data processing software (ProMAX) for enhancement of seismic images.

[8] Gamma density (wet bulk density) of the whole core was measured on board using a GEOTEK Multisensor Core Logger (MSCL) following standard GEOTEK calibration and measurement protocol (http://www.geotek.co.uk/ftp/manual.pdf). The porosity $(\phi)$ can be derived from the wet bulk density $\left(\rho_{M S C L}\right)$ assuming that the sediment is fully saturated with water and the grain $\left(\rho_{s}=2.65 \mathrm{~g} / \mathrm{cc}\right)$ and fluid $\left(\rho_{f l}=1.03 \mathrm{~g} / \mathrm{cc}\right)$ densities are known,

$$
\rho_{M S C L}=\phi \rho_{f l}+(1-\phi) \rho_{s}
$$

[9] Mineralogical identification was carried out using a Philips X-ray diffractometer (PW1840). All the carbonate samples were run from 25 to $32^{\circ} 2 \theta$ at $1^{\circ} / \mathrm{min}$ scan speed using $\mathrm{CuK} \alpha$ radiation $(\lambda=1.541838 \AA)$. MgCO3 content in the carbonate samples was measured following Goldsmith et al. [1961]. A SEM (JEOL JSM-5800LV) was used for microstructural studies of the carbonates.

[10] Moisture content in the sediment was calculated from the difference in wet and dry weight of sediments. Sediments were dried at $105^{\circ} \mathrm{C}$.

\subsection{Geochemical Methods}

[11] A PVC liner with $10 \mathrm{~cm}$ inner diameter was used for core collection. Subsampling for gas and pore water was carried out at one meter intervals within one and a half hour of core retrieval. Subsampling for gas was carried out using a $10 \mathrm{ml}$ cut syringe. Sediment was stored in $28 \mathrm{ml}$ glass vials with $10 \mathrm{ml}$ of bacteriacide (sodium azide) and crimped immediately following nitrogen flushing. Sediment was homogenized using a vortex shaker and stored at $2^{\circ} \mathrm{C}$ until concentrations of hydrocarbon $\left(\mathrm{CH}_{4}, \mathrm{C}_{2} \mathrm{H}_{6}\right.$ and $\left.\mathrm{C}_{3} \mathrm{H}_{8}\right)$ gases in the head space were measured using a Varian Gas chromatograph (CP 3380). Pore water was extracted from the sediment using a hydraulic press following standard ODP protocol [Shipboard Scientific Party, 2000]. Pore waters were collected in $20 \mathrm{ml}$ plastic syringes with Leur locks. They were filtered through a $0.2 \mu \mathrm{m}$ Whatman syringe filter and stored in crimp vials under nitrogen head and preserved at $2^{\circ} \mathrm{C}$. Sulfate concentrations were measured using a Dionex-600 ion chromatograph [Gieskes et al., 1991]. Total alkalinity, $\mathrm{pH}$ and chloride concentrations 
were measured using a Metrohm Autotitrator (Titrino 799GPT).

[12] Total carbon (TC) content of sediments was measured by elemental analyzer (Thermo CNS 2500). Total inorganic carbon (TIC) content was measured by UIC carbon coulometer (CM 5130). Total organic carbon (TOC) was calculated by subtracting TIC from TC.

[13] Carbon and oxygen stable isotope ratio measurements of head space gases and carbonates were carried out using a Thermo-Finnigan Delta Plus continuous flow isotope ratio mass spectrometer attached with gas chromatograph and Gas Bench II. The external precision calculated is typically $0.07-0.09 \%$ VPDB for $\delta^{13} \mathrm{C}$ and $0.06-0.12 \%$ VPDB for $\delta^{18} \mathrm{O}$.

[14] Sixteen AMS ${ }^{14} \mathrm{C}$ dates were generated at National Ocean Sciences AMS (NOSAMS) facility, Woods Hole Oceanographic Institution, USA. Dates were determined on planktonic foraminifera species Globigerina ruber and Globigerina sacculifer. Carbon dioxide generated from these foraminifera shells is reacted with catalyst to form graphite which is pressed into targets and analyzed on the accelerator along with standards and process blanks. Two primary standards used during ${ }^{14} \mathrm{C}$ measurements are NBS Oxalic Acid I (NIST-SRM4990) and Oxalic Acid II (NIST-SRM-4990C).

[15] Two tube shaped authigenic carbonates collected from the carbonate-rich horizon (16 mbsf) were samples for $U$ and $T h$ concentration and isotopic measurements. The samples were spiked with a mixed ${ }^{229} \mathrm{Th}-{ }^{236} \mathrm{U}$ spike, dissolved in concentrated $\mathrm{HNO}_{3}$, and then centrifuged in order to separate any silicate-rich residue from the carbonate solution; the residue was treated separately with hydrofluoric acid. Th and $U$ of both the carbonate portions and the silicate residues were purified by traditional, anionic chromatographic exchange chemistry methods [e.g., Ivanovich and Harmon, 1992]. U and Th isotope ratios were measured with MC-ICPMS (Thermo-Finnigan Neptune) at University of Bristol by bracketing $\mathrm{U}$ measurements with U112a standard, and Th measurements with the in-house "TEDDi" Th standard. The accuracy and precision of the measurements are continually monitored by the analysis of secular equilibrium standards such as TML, HU, ThA, and WUN [Hoffmann et al., 2007].

\subsection{Computational Methods: Carbonate Content}

[16] The bulk density $\left(\rho_{b}\right)$ of the sampled sediment can be derived from the moisture content $\left(W_{b}\right)$, fluid $\left(\rho_{f l}\right)$ and grain densities $\left(\rho_{s}=2.65 \mathrm{~g} / \mathrm{cc}\right)$ assuming that the sediment is fully saturated with water:

$$
\begin{gathered}
W_{b}=\frac{M_{p w}}{M_{b}}=\frac{V_{p w} \rho_{f l}}{V_{b} \rho_{b}}=\frac{\phi \rho_{f l}}{\rho_{b}}, \\
\rho_{b}=\phi \rho_{f l}+(1-\phi) \rho_{s},
\end{gathered}
$$

where $M_{p w}$ and $V_{p w}$ are the mass and volume of pore water, respectively, and $M_{b}$ and $V_{b}$ are the mass and volume of bulk sample, respectively. $\phi$ represents sediment porosity.

[17] Substituting equation (2) into equation (3) and further simplifying we obtain the bulk density of the sample:

$$
\rho_{b}=W_{b} \rho_{b}+\left(1-\frac{W_{b} \rho_{b}}{\rho_{f l}}\right) \rho=\frac{\rho_{s}}{1-W_{b}+\frac{W_{b} \rho_{s}}{\rho_{l}}} .
$$

[18] In the absence of carbonates, the bulk density calculated from the moisture content should be equal to the density measured from MSCL. The presence of carbonates increases the MSCL-derived bulk density $\left(\rho_{M S C L}\right)$, whereas the density calculated from moisture content is assumed to be unchanged as it represents a small fraction of the core presumably free of carbonates. This scenario can be modeled by considering a two-phase system, where the matrix is assumed to be marine sediment and carbonate is considered to be an inclusion:

$$
\rho_{M S C L}=S \rho_{\text {carb }}+(1-S) \rho_{b} .
$$

$\mathrm{S}$ represents the carbonate fraction and $\rho_{\text {carb }}$ is the density $(2.71 \mathrm{~g} / \mathrm{cc})$ of carbonate.

\section{Results}

\subsection{Geophysical and Geological Results}

[19] The structures and characteristics of reflection echoes in the high-resolution, subbottom profiler data (Figure 2) suggest two distinct geological strata: acoustically transparent layers (DF1 to DF4) having semiprolonged bottom echo with regular overlapping hyperbolae characterizing mass wasting [Pratson and Laine, 1989], and distinct, parallel, continuous reflectors having a mound like structure. Four distinct layers (DF 1-4) are seen onlapping onto the mud-mound feature. The top layer DF-4 can be traced over the mound and is parallel to the subsurface depression. 


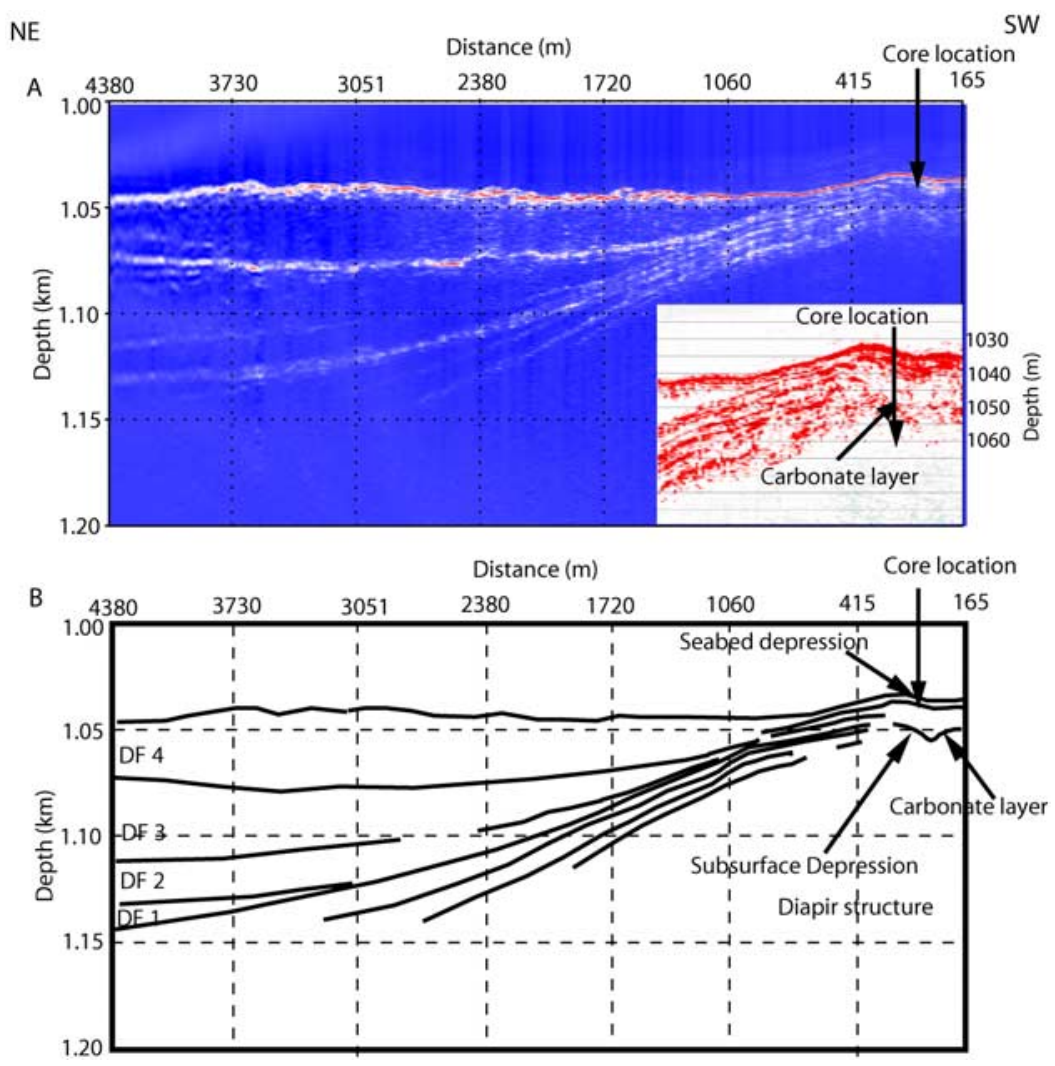

Figure 2. Subbottom profiler (SBP) image. (a) High-resolution subbottom profiler data collected on board R/V Marian Dufresne. The horizontal distance is plotted with respect to the core location. The inset shows close-up of the subsurface depression. Depths are below the sea surface; note scale change in the inset. (b) Line drawing of the major features observed in SBP data. Layered mud diapir structure is overlain by seismically amorphous layers (DF1-DF4).

[20] The wet bulk density data (Figure 3a) of the whole core show a zone of enhanced density relative to the background at $16-18 \mathrm{mbsf}$. Two additional density hikes are noticed at 18.5 and 19.7 mbsf. Calculated (equation (5)) carbonate content in the high-density layers range from $\sim 10$ to 55 vol \% (6 D). The carbonate-enriched zone apparently coincides with a subsurface depression as observed in the SBP data (Figure 2). This zone is enriched in hard, authigenic carbonates of variable morphological types.

[21] Light to medium gray authigenic micritic carbonates and brown-colored chemosynthetic clam shells (Figures $4 \mathrm{a}-4 \mathrm{j}$ ) are present predominantly within 16 to $18 \mathrm{mbsf}$. The following carbonate morphological types are observed: massive mudstone concretions (MC), vacuolar mudstone concretions with gas flow channels (VMC), tubule and vase-shaped bioturbation casts (BC) with or without laminations, cemented breccias $(\mathrm{BrC})$, chimneys (Ch), filling within shells (SF) and nodular (Nd) types. BCs show thick and thin branching appendages. Chimneys are often filled with carbo- nates leaving only narrow orifices. Mineralogically authigenic carbonates are composed of high-magnesium calcites with $\mathrm{MgCO}_{3}$ content ranging from $8 \mathrm{~mol} \%$ to $20 \mathrm{~mol} \mathrm{\%} \mathrm{(} \pm 1 \mathrm{~mol} \%$ ) (Table 1$)$, whereas the clam shells are aragonitic in composition. Needle shaped aragonite crystals are present

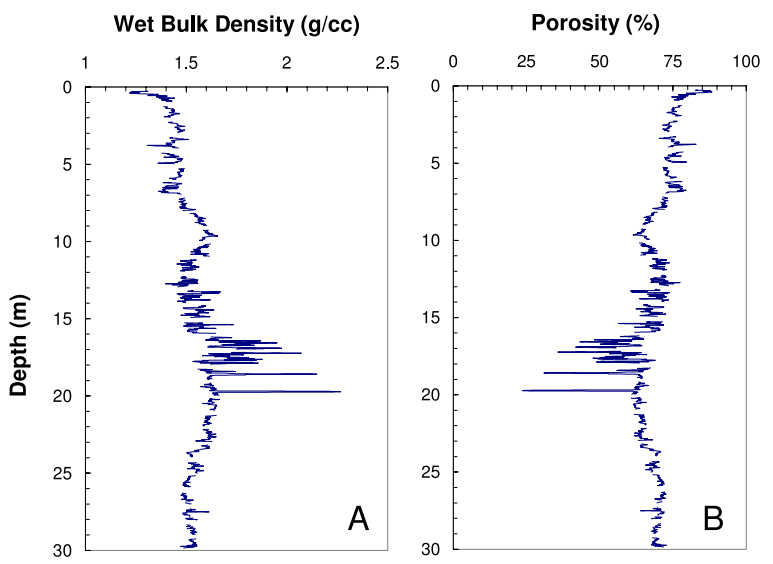

Figure 3. (a) Wet bulk density and (b) calculated porosity profiles. 


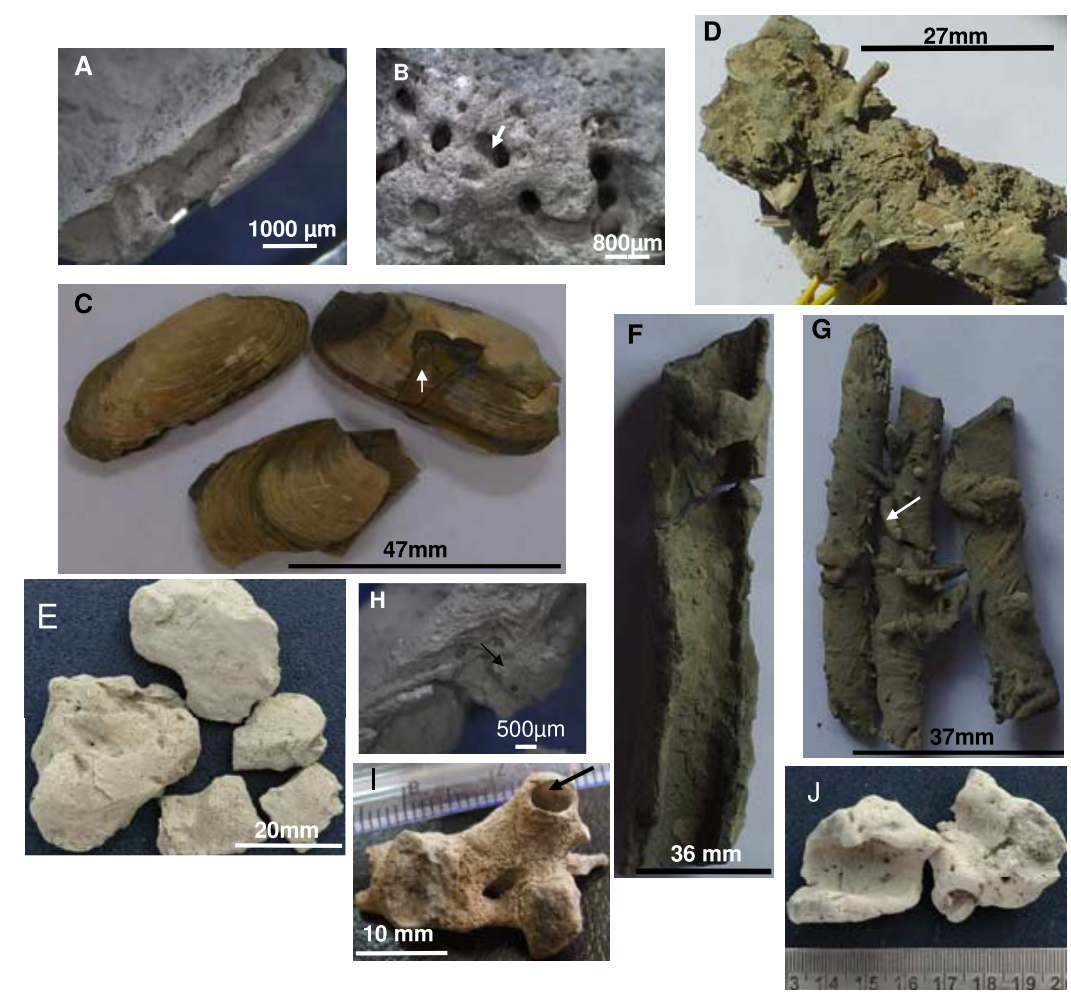

Figure 4. Morphology of authigenic carbonates and shells. (a) Mudstone concretion (VMC) with gas flow conduit (8/17D). (b) Mudstone concretion (8/17D) with globular vacuules (arrow). (c) Whole shells (Sh) and fragments of Calyptogena sp. (8/17B) with carbonate filling (arrow). (d) Cemented breccia $(\mathrm{BrC})$ with chaotically oriented Calyptogena shells, bioturbation casts, and mudstone clasts (8/17 G). (e) Massive mudstone concretion (MC: 8/17C). (f) Part of a chimney (Ch) showing variable wall thickness. Chimney wall is often pitted (8/18 I). (g) Tubular bioturbation casts (BC) showing appendage-like structures and filling of ovular carbonate pellets (8/18 A). (h) Tubular bioturbation cast $(\mathrm{BC}: 8 / 18 \mathrm{~L}$ ) with curved laminations (arrow). (i) Chimney $(8 / 18 \mathrm{M})$ with inner lining of aragonite (arrow). (j) White colored chimney with porous surface (8/18 J).

as lining within gas chimneys or as cavity fillings (Figures 4i, 5a, and 5b). Isolated and clusters of framboidal pyrites $(10-20 \mu \mathrm{m})$ are present in all the carbonate types (Figures $5 \mathrm{c}$ and $5 \mathrm{~d}$ ). Foraminifera tests are often filled with pyrite framboids or completely replaced by pyrite. Numerous wellpreserved and fragmented shells of chemosynthetic clam, Calyptogena sp. (Figure 4c) were recorded between 16 to 18 mbsf. Concretions and small tubules of authigenic carbonates have also been recorded above and below this zone in minor amounts.

\subsection{Geochemical Results}

[22] The pore water sulfate concentration profile (Figure 6a) shows four distinct gradients viz., I $(0.032 \mathrm{mM} / \mathrm{cm})$, II $(0.0038 \mathrm{mM} / \mathrm{cm})$, III $(0.034 \mathrm{mM} / \mathrm{cm})$ and IV $(0.000429 \mathrm{mM} / \mathrm{cm})$ as marked on the profile. Total alkalinity (TA) shows a peak (13.2 mM) within 3-5 mbsf followed by sharp fall to $7.4 \mathrm{mM}$ at $7.35 \mathrm{mbsf}$.
This is followed by a steady rise in TA to $25 \mathrm{mM}$ at $22.5 \mathrm{mbsf}$ and a subsequent drop to $20 \mathrm{mM}$ at 29 mbsf. $\mathrm{CH}_{4}$ concentration shows a sharp rise at 17 mbsf which is followed by low concentrations possibly owing to methane loss during sampling. A double arrow (at 13 to $17 \mathrm{mbsf}$ ) has been drawn to show the approximate zone of anaerobic methane oxidation (AMO). The $\mathrm{C}_{1} /\left(\mathrm{C}_{2}+\mathrm{C}_{3}\right)$ ratios (Table 1) of hydrocarbon gases drop rapidly within the AMO zone. Below this zone the ratio increases to a maximum of 3945 with intermediate minima of 1100 at 24 mbsf. $\delta^{13} \mathrm{C}_{\mathrm{CH} 4}$ drops to a minimum of $-85.2 \%$ VPDB at the base of the AMO zone. $\delta^{13} \mathrm{C}_{\mathrm{CO} 2}$ broadly follows the $\delta^{13} \mathrm{CH}_{4}$ trend (Figure $4 \mathrm{c}$ ) and drops to a minima of $-26.3 \%$ VPDB. The chloride concentration (542 to $564 \mathrm{mM}$ ) shows a gentle gradient of $0.28 \mathrm{mM} / \mathrm{m}$ down to a $29 \mathrm{~m}$ depth (Figure 6b).

[23] Authigenic carbonates have highly depleted carbon isotope compositions (Figure 7), with $\delta^{13} \mathrm{C}$ values ranging from -41.3 to $-52.4 \%$ VPDB 
Table 1. Pore Water, Gas Composition, and Carbon Stable Isotope Ratios of Methane and Carbon Dioxide ${ }^{\mathrm{a}}$

\begin{tabular}{|c|c|c|c|c|c|c|c|c|c|c|}
\hline Depth (m) & $\begin{array}{l}{ }^{14} \text { C Age } \\
\text { (years B.P.) }\end{array}$ & $\begin{array}{l}\text { Mean Cal Age } \\
\text { (years B.P.) }\end{array}$ & $\begin{array}{c}\mathrm{TA} \\
(\mathrm{mM})\end{array}$ & $\begin{array}{c}\text { TOC } \\
\text { (wt \%) }\end{array}$ & $\begin{array}{l}\mathrm{CH}_{4} \\
(\mu \mathrm{M})\end{array}$ & $\mathrm{C}_{1} /\left(\mathrm{C}_{2}+\mathrm{C}_{3}\right)$ & $\begin{array}{c}\text { Sulfate } \\
(\mathrm{mM})\end{array}$ & $\begin{array}{l}\text { Chloride } \\
(\mathrm{mM})\end{array}$ & $\begin{array}{c}\delta^{13} \mathrm{C} \mathrm{CH}_{4} \\
(\%)(\mathrm{VPDB})\end{array}$ & $\begin{array}{c}\delta^{13} \mathrm{C} \mathrm{CO}_{2} \\
(\%)(\mathrm{VPDB})\end{array}$ \\
\hline 0.05 & $910 \pm 35$ & $528 \pm 19$ & 4.6 & 1.3 & 12.1 & 7.3 & 29.1 & 551 & -61.1 & -16.6 \\
\hline 1.055 & $1370 \pm 40$ & $895 \pm 47$ & 6.8 & 1.3 & 9.8 & 48.0 & 26.7 & 564 & & \\
\hline 2.055 & $1750 \pm 35$ & $1282 \pm 19$ & 10.3 & 1.6 & 33.2 & 247.1 & 22.2 & 549 & -67.2 & -18.6 \\
\hline 3.055 & $2210 \pm 45$ & $1738 \pm 59$ & 13.2 & 1.6 & 43.4 & 351.9 & 20.0 & 545 & & \\
\hline 4.055 & $3140 \pm 35$ & $2824 \pm 38$ & 13.2 & 1.9 & 61.5 & 169.7 & 19.4 & 544 & -67.6 & -20.8 \\
\hline 5.055 & & & 13.2 & 1.8 & 40.6 & 185.2 & 18.5 & 542 & & \\
\hline 6.055 & $4910 \pm 50$ & $5184 \pm 110$ & 11.3 & 2.0 & 86.3 & 227.2 & 18.6 & 547 & & \\
\hline 7.055 & $7340 \pm 50$ & $7762 \pm 59$ & 9.7 & 1.6 & 1.0 & & 17.5 & 552 & & \\
\hline 8.055 & $11900 \pm 60$ & $13361 \pm 78$ & 8.6 & 1.7 & 52.9 & & 16.9 & 549 & & \\
\hline 9.055 & $15600 \pm 75$ & $18443 \pm 119$ & 7.9 & 1.4 & 28.6 & & 17.7 & 551 & & \\
\hline 10.055 & $19900 \pm 95$ & $23261 \pm 186$ & 7.4 & 1.4 & 31.7 & & 17.4 & 545 & -68.8 & -18.9 \\
\hline 11.055 & $26400 \pm 140$ & $31232 \pm 203$ & 8.7 & 1.4 & 85.4 & 681.7 & 16.8 & 552 & & \\
\hline 12.055 & $40600 \pm 400$ & $44900 \pm 401$ & 9.4 & 1.7 & 108.8 & & 16.0 & 553 & & \\
\hline 13.055 & $37200 \pm 300$ & $41962 \pm 311$ & 10.3 & 2.0 & 141.5 & 830.0 & 17.6 & 545 & -70.7 & -26.3 \\
\hline 14.055 & & & 10.5 & 1.7 & 101.6 & 1243.5 & 13.5 & 545 & & \\
\hline 15.055 & & & 12.6 & 1.8 & 292.7 & 1048.0 & 10.4 & 543 & & \\
\hline 16.055 & $36000 \pm 350$ & $40901 \pm 362$ & 14.1 & 1.8 & 484.4 & 2284.4 & 6.2 & 556 & & \\
\hline 17.055 & $37800 \pm 300$ & $42480 \pm 313$ & 14.8 & 1.4 & 2224.9 & 3354.2 & 4.1 & 561 & -85.2 & -25.3 \\
\hline 18.055 & & & 18.3 & 2.0 & 516.8 & 3117.2 & 3.1 & 544 & & \\
\hline 19.055 & $39100 \pm 430$ & $43594 \pm 412$ & 16.6 & 1.5 & 511.4 & 2786.0 & 2.9 & 555 & & \\
\hline 20.055 & & & 18.9 & 1.1 & 443.9 & 3392.9 & 3.2 & 556 & & \\
\hline 21.055 & & & 19.7 & 1.4 & 370.5 & 2499.8 & 2.2 & 550 & -77.4 & -17.7 \\
\hline 22.055 & & & 21.2 & 1.5 & 409.4 & 1873.5 & 2.4 & 562 & & \\
\hline 23.055 & & & 22.8 & 1.4 & 481.3 & 3290.5 & 1.4 & 550 & & \\
\hline 24.055 & & & 23.1 & 1.9 & 433.5 & 1100.3 & 1.3 & 555 & -75.4 & -15.3 \\
\hline 25.055 & & & 22.4 & 2.0 & 744.7 & 3945.4 & 2.3 & 552 & & \\
\hline 26.055 & & & 22.5 & 2.0 & 815.3 & 3359.5 & 2.4 & 553 & & \\
\hline 27.055 & & & 20.9 & 2.0 & 827.9 & 3907.7 & 3.3 & 554 & & \\
\hline 28.055 & & & 21.2 & & 747.0 & 3919.6 & 2.4 & 560 & -75.7 & -13.8 \\
\hline 29.055 & & & 20.0 & 1.8 & 644.7 & 2784.9 & 2.8 & 561 & & \\
\hline
\end{tabular}

\footnotetext{
${ }^{\mathrm{a}}$ The errors in calendar age are represented as one sigma standard deviation. TA, total alkalinity; TOC, total organic carbon.
}

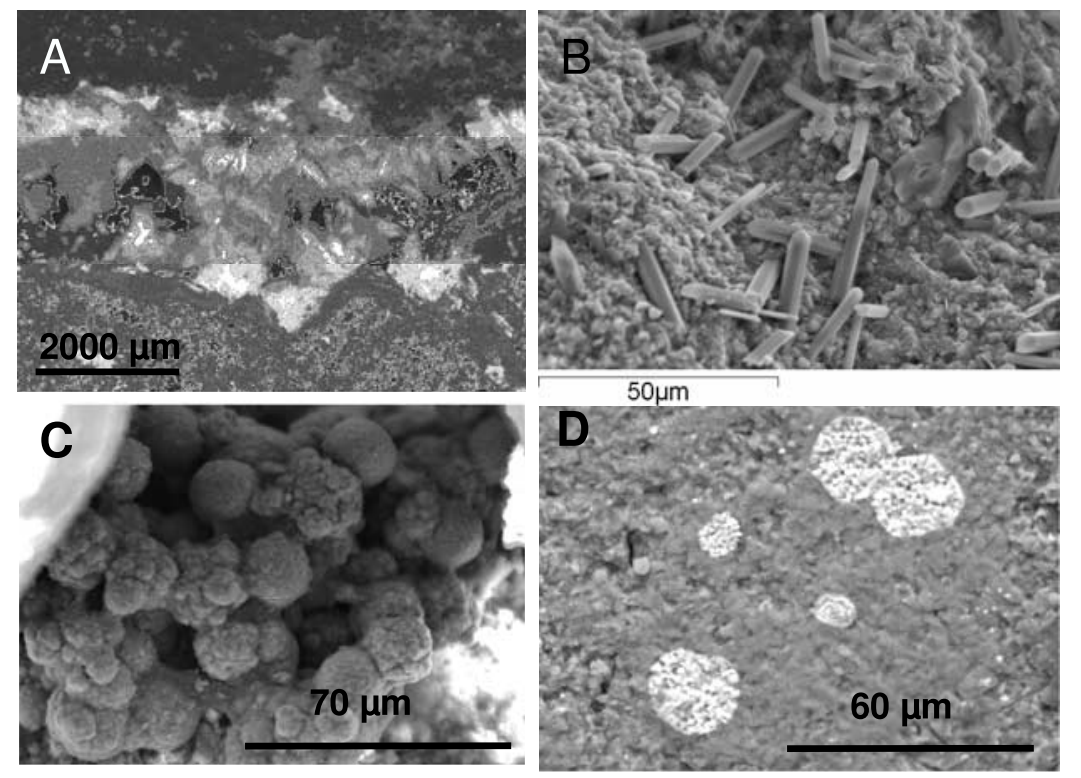

Figure 5. Microstructures of authigenic carbonates. (a) Acicular aragonite crystals as lining along an elongated cavity (8/18M). (b) Aragonite crystals as seen under SEM (8/18M). (c) Cluster of framboidal pyrite (8/18A). (d) Rounded and polygonal pyrite framboides (8/18B). 


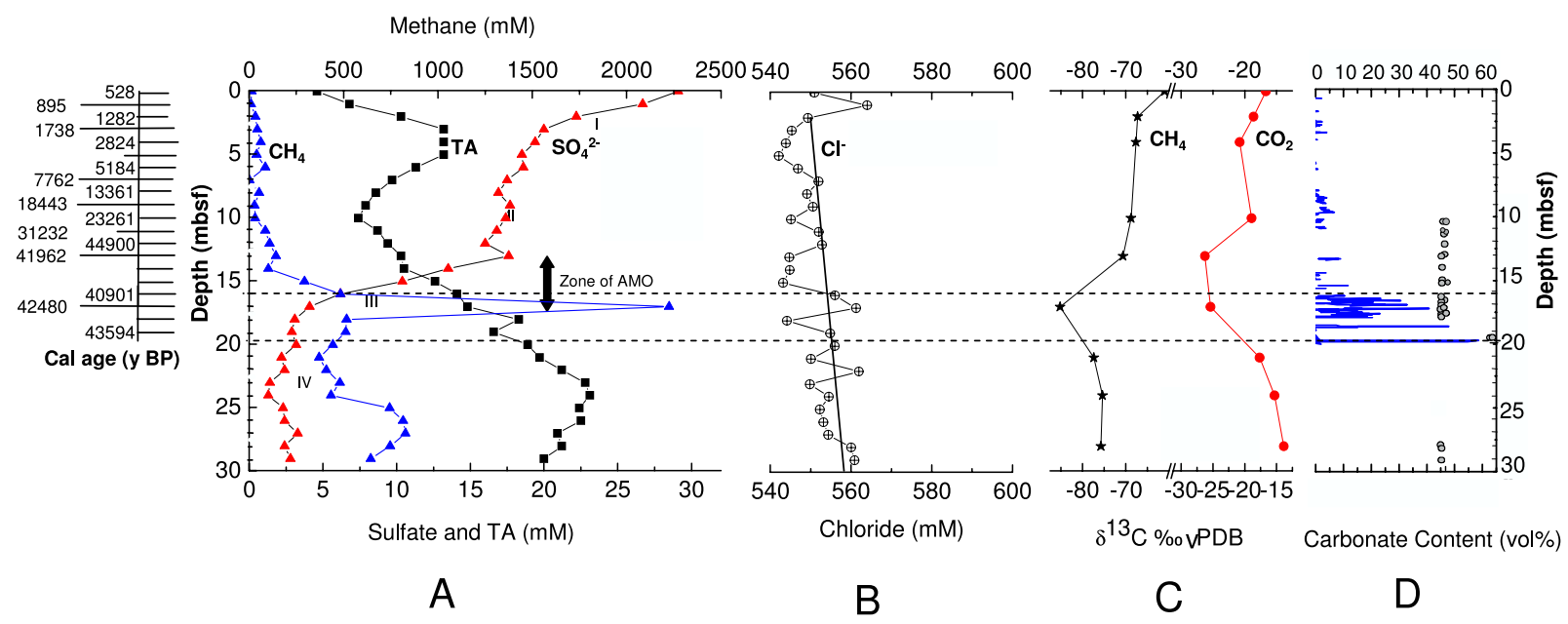

Figure 6. Composition of pore fluids and carbonate content in the sediment. (a) Sulfate $\left(\mathrm{SO}_{4}^{2-}\right.$, $\mathrm{mM}$ ), alkalinity (TA, mM), and methane $\left(\mathrm{CH}_{4}, \mu \mathrm{M}\right)$ concentration profiles. Approximate zone of anerobic methane oxidation is shown by double arrow. Calendar ages are marked against the corresponding depths (mbsf). Different sulfate concentration gradients are marked as I-IV. (b) Chloride $\left(\mathrm{Cl}^{-}, \mathrm{mM}\right)$ concentration profile. The solid line through the profile shows the chloride concentration gradient. (c) Carbon isotopic composition $\left(\delta^{13} \mathrm{C}, \%\right.$ VPDB) of methane and carbon dioxide gases in the headspace. Note the ${ }^{13} \mathrm{C}$ enrichment in the residual methane above AMO. (d) Approximate carbonate content (vol \%) calculated from MSCL based wet bulk density. The sharp peaks are due to the presence of authigenic carbonate layers. Carbonate sampling locations are marked by dots. Dashed lines demarcate the zoned of enriched carbonate layers.

(Table 2). In contrast, $\delta^{13} \mathrm{C}$ values of bivalve shells range from -1.0 to $-1.1 \%$ VPDB. The $\delta^{18} \mathrm{O}$ values of authigenic carbonates are within 3.2 to $5.2 \%$ VPDB. TOC content ranges from 1 to $2 \%$ and does not show any systematic depth wise variation (Table 1).

[24] Depth versus calendar age is presented in Figure 8. Radiocarbon ages are converted to mean calendar ages (Table 1) following the calibration curve of Fairbanks et al. [2005] and the calibration software (http://radiocarbon.ldeo.columbia.edu/research/radcarbcal.htm). Figure 8 shows high sedimentation rates $(248.3$ to $86 \mathrm{~cm} / \mathrm{ka}$ ) for the upper 5 to $6 \mathrm{mbsf}$ of sediment. At $7 \mathrm{mbsf}$, the sedimentation rate drops abruptly to $17.5 \mathrm{~cm} / \mathrm{ka}$ and remains constant until $13 \mathrm{mbsf}$, thereafter, systematic increase of ${ }^{14} \mathrm{C}$ age with depth ceases.

[25] $\left({ }^{230} \mathrm{Th} /{ }^{238} \mathrm{U}\right)$ activity ratios of the two authigenic carbonate samples collected at $16 \mathrm{mbsf}$ within the carbonate rich layer are $0.631 \pm 0.002$ and $0.771 \pm 0.003$; measured $\left({ }^{234} \mathrm{U} /{ }^{238} \mathrm{U}\right)$ values were $1.121 \pm 0.002$ and $1.133 \pm 0.002$ (parentheses denote activity ratios, all errors are 2-sigma and fully propagated [see Hoffmann et al., 2007]). ${ }^{230} \mathrm{Th}-{ }^{234} \mathrm{U}$ ages were calculated using IsoPlot [Ludwig and Titterington, 1994]. Given the high Th content of the authigenic carbonates $(\sim 2.3 \mathrm{ppm}$ $\mathrm{Th}$ in both) a correction for initial detrital ${ }^{230} \mathrm{Th}$ is necessary. This correction was made adopting the $\left({ }^{230} \mathrm{Th} /{ }^{232} \mathrm{Th}\right)$ of the silicate-rich residue after leaching as representative of the detrital Th isotope composition [Teichert et al., 2003] assuming detritus in secular equilibrium. This calculation provided ages estimates of $46.2 \pm 3.7$ and $53.0 \pm 1.6 \mathrm{ka}$ for the two tubular authigenic carbonates and initial

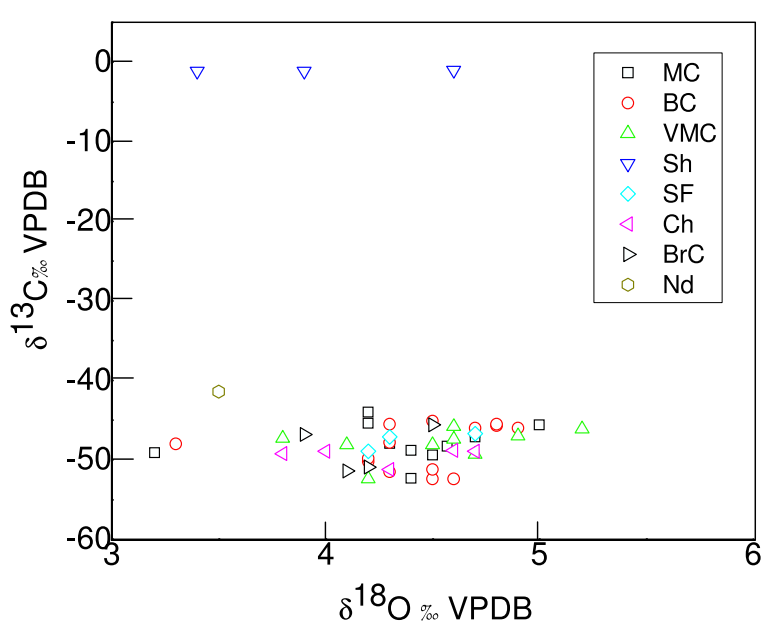

Figure 7. Crossplot of carbon and oxygen stable isotopic compositions of authigenic carbonates and shells. Carbonate morphological types are explained in Figure 4. 
Table 2. Authigenic Carbonate Morphological Types, Mineralogy, and Carbon and Oxygen Stable Isotope Ratios ${ }^{\mathrm{a}}$

\begin{tabular}{|c|c|c|c|c|c|}
\hline $\begin{array}{l}\text { Sample } \\
\text { Number }\end{array}$ & Depth (m) & Morphology & $\begin{array}{c}\mathrm{Mg} \\
(\mathrm{mol} \%)\end{array}$ & $\begin{array}{l}\delta^{13} \mathrm{C}(\%) \\
(\mathrm{VPDB})\end{array}$ & $\begin{array}{l}\delta^{18} \mathrm{O}(\%) \\
(\mathrm{VPDB})\end{array}$ \\
\hline $8 / 11 \mathrm{~A}$ & 10.05 & Mudstone concretions & 14 & -49.4 & 4.5 \\
\hline $8 / 11 \mathrm{~B}$ & 10.05 & Mudstone concretions & $\mathrm{nm}$ & -45.6 & 5.0 \\
\hline $8 / 12 \mathrm{~A}$ & 11.05 & Tubular burrow filling & 11 & -45.7 & 4.8 \\
\hline $8 / 12 \mathrm{~B}$ & 11.2 & Cavernous mudstone concretion with channels & 9 & -46.1 & 5.2 \\
\hline $8 / 12 \mathrm{C}$ & 11.5 & Cavernous mudstone concretion with channels & 14 & -45.8 & 4.6 \\
\hline $8 / 13$ & 12.1 & Tubular burrow filling & 17 & -45.5 & 4.3 \\
\hline $8 / 14 \mathrm{~A}$ & 13.05 & Cavernous mudstone concretion with channels & 15 & -47.4 & 4.6 \\
\hline $8 / 14 B$ & 13.25 & Cavernous mudstone concretion with channels & 20 & -49.3 & 4.7 \\
\hline $8 / 15$ & 14.05 & Tubular burrow filling & 12 & -52.4 & 4.6 \\
\hline $8 / 16 \mathrm{~A}$ & 15 & Shell & $\arg$ & -1.0 & 4.6 \\
\hline $8 / 16 \mathrm{~B}$ & 15 & Tubular burrow filling & 14 & -47.8 & 4.3 \\
\hline $8 / / 16$ & 15.15 & Cavernous mudstone concretion with channels & $\mathrm{nm}$ & -52.4 & 4.2 \\
\hline $8 / 16 / 1541$ & 15.41 & Mudstone concretions & 15 & -48.8 & 4.4 \\
\hline $8 / 17 \mathrm{~A}$ & 16.05 & Mudstone concretions & 16 & -52.3 & 4.4 \\
\hline $8 / 17 \mathrm{~B}$ & 16.15 & Shell & $\arg$ & -1.1 & 3.4 \\
\hline $8 / 17 \mathrm{C}$ & 16.2 & Mudstone concretions & 17 & -44.0 & 4.2 \\
\hline $8 / 17 \mathrm{D}$ & 16.2 & Cavernous mudstone concretion with channels & $\mathrm{nm}$ & -48.1 & 4.1 \\
\hline $8 / 17 \mathrm{E}$ & 16.2 & Cavernous mudstone concretion with channels & $\mathrm{nm}$ & -48.1 & 4.5 \\
\hline $8 / 17 \mathrm{~F}$ & 16.3 & Mudstone concretions & $\mathrm{nm}$ & -47.9 & 4.3 \\
\hline $8 / 17 \mathrm{G}$ & 16.35 & breccia cement & 16 & -45.6 & 4.5 \\
\hline $8 / / 17 \mathrm{H}$ & 16.6 & Shell filling & 12 & -47.1 & 4.3 \\
\hline $8 / / 17 \mathrm{I}$ & 16.65 & breccia cement & 14 & -46.8 & 3.9 \\
\hline $8 / 17 / 1650$ & 16.65 & Shell & $\arg$ & -1.1 & 3.9 \\
\hline $8 / 17 / \mathrm{B} 1 / 1652$ & 16.7 & Shell filling & 15 & -48.9 & 4.2 \\
\hline $8 / 17 / \mathrm{B} 4 / 1650$ & 16.7 & Shell filling & 18 & -46.7 & 4.7 \\
\hline $8 / 18 \mathrm{~A}$ & 17.05 & Tubular burrow filling & 19 & -45.1 & 4.5 \\
\hline $8 / 18 \mathrm{~B}$ & 17.05 & Tubular burrow filling & 16 & -45.5 & 4.8 \\
\hline $8 / 18 \mathrm{C}$ & 17.15 & Mudstone concretions & 16 & -47.1 & 4.7 \\
\hline $8 / 18 \mathrm{D}$ & 17.22 & Mudstone concretions & 9 & -45.4 & 4.2 \\
\hline $8 / 18 \mathrm{E}$ & 17.35 & Cavernous mudstone concretion with channels & 13 & -47.0 & 4.9 \\
\hline $8 / 18 \mathrm{~F}$ & 17.4 & Tubular burrow filling & 11 & -46.0 & 4.9 \\
\hline $8 / 18 \mathrm{G}$ & 17.42 & Mudstone concretions & 18 & -46.5 & 4.7 \\
\hline $8 / 18 \mathrm{H}$ & 17.5 & Tubular burrow filling & 14 & -46.0 & 4.7 \\
\hline $8 / 18 \mathrm{I}$ & 17.55 & Chimney & 15 & -48.9 & 4.7 \\
\hline $8 / 18 \mathrm{~J}$ & 17.6 & Chimney & $\mathrm{nm}$ & -48.8 & 4.6 \\
\hline $8 / 18 \mathrm{~K}$ & 17.65 & Vase shaped burrow filling & 16 & -49.8 & 4.2 \\
\hline $8 / 18 \mathrm{~L}$ & 17.7 & Tubular burrow filling & 18 & -51.2 & 4.5 \\
\hline $8 / 18 \mathrm{M}$ & 17.85 & Chimney & 18 & -51.2 & 4.3 \\
\hline $8 / 18 \mathrm{~N}$ & 17.9 & Mudstone concretions & $\mathrm{nm}$ & -49.1 & 3.2 \\
\hline $8 / 180$ & 17.93 & breccia cement & $\mathrm{nm}$ & -50.9 & 4.2 \\
\hline $8 / 18 \mathrm{P}$ & 17.95 & breccia cement & 17 & -51.4 & 4.1 \\
\hline $8 / 18 Q$ & 17.95 & Tubular burrow filling & 18 & -51.5 & 4.3 \\
\hline $8 / 18 \mathrm{R}$ & 17.97 & Chimney & 18 & -48.9 & 4.0 \\
\hline $8 / 19 \mathrm{~A}$ & 18.05 & Tubular burrow filling with pellets & $\mathrm{nm}$ & -50.2 & 4.2 \\
\hline $8 / 19 B$ & 18.05 & vase shaped burrow filling & 10 & -48.0 & 3.3 \\
\hline $8 / 19 \mathrm{C}$ & 18.5 & Chimney & 18 & -49.2 & 3.8 \\
\hline $8 / 20 \mathrm{~A}$ & 19.55 & Vase shaped burrow filling & $\mathrm{nm}$ & -52.4 & 4.5 \\
\hline $8 / 20 / \mathrm{A} 1 / 1965$ & 19.65 & Mudstone concretions & 18 & -48.3 & 4.6 \\
\hline $8 / 29$ & 28.05 & mudstone concretion & 17 & -47.3 & 3.8 \\
\hline $8 / 30$ & 29.05 & Nodular & 18 & -41.4 & 3.5 \\
\hline
\end{tabular}

${ }^{a}$ Abbreviations are as follows: $\mathrm{nm}$, not measured; arg, aragonite.

$\left({ }^{234} \mathrm{U}^{238} \mathrm{U}\right)_{\mathrm{o}}=1.357 \pm 0.031$ and $1.206 \pm 0.011$, respectively. The latter are higher than values estimated for seawater (1.14-1.15 [Chen et al., 1986; Delanghe et al., 2002]), requiring alpha recoil processes [Kigoshi, 1971] and thus suggesting a major role for pore waters in the formation of the authigenic carbonates [Teichert et al., 2003]. Additional U-Th measurements are required to evaluate whether local sediments share $\left({ }^{230} \mathrm{Th} /{ }^{232} \mathrm{Th}\right)$ with the residue (see Watanabe et al., 2008), and thus the accuracy of the detrital correction, in order to 


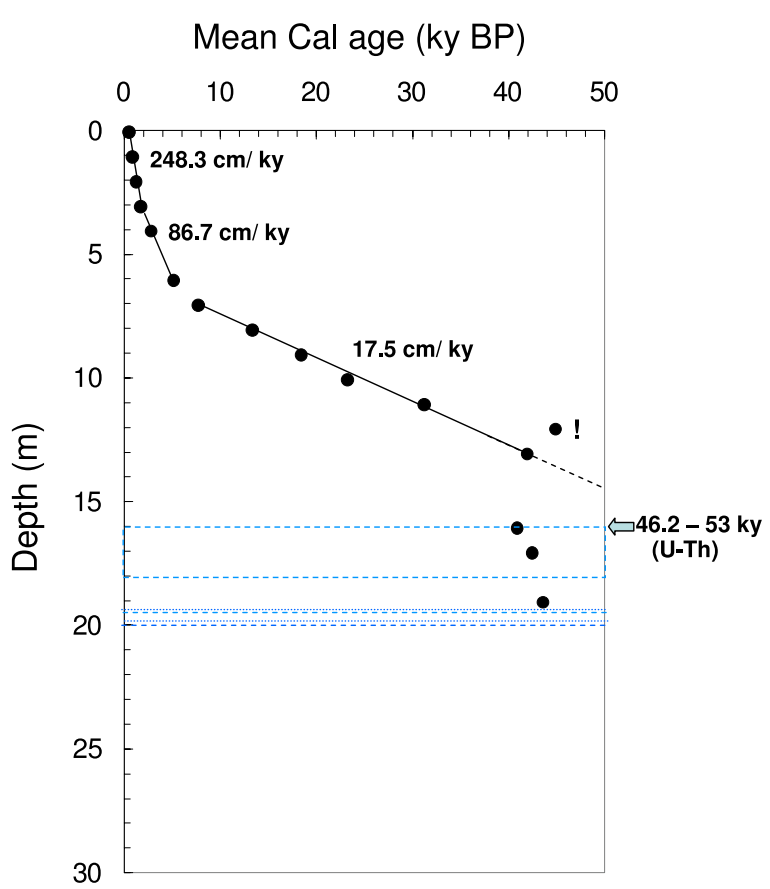

Figure 8. Sedimentation rate variations at the studied site. Dotted boxes demarcate the carbonate enriched layers. Dashed lines show extrapolation of calendar ages. U-Th dates are marked against the sampling depth (mbsf). The errors in calendar age are represented as one sigma standard deviation. The point highlighted by an exclamation mark is a possible outlier.

eventually put further time constraint on the carbonate formation events.

\section{Discussion}

\subsection{Authigenic Carbonates: Evidence of Paleoseep}

[26] The most important evidence for paleoseepage of methane and sulfidic fluid at this site comes from the record of numerous well-preserved and fragmented shells of chemosynthetic clam, Calyptogena sp. (Figure 4c). Definite association of Calyptogena sp. with methane seeps has been demonstrated from numerous cold seep locations [Kulm et al., 1986; Hashimoto et al., 1995; Sibuet and Olu, 1998; Levin, 2005; Sahling et al., 2002, 2005, 2008]. The chemosynthetic clams rely on sulfide-oxidizing endosymbionts in the gill tissues for survival. Abundant pyrite as isolated crystals and framboid clusters in the carbonate matrix suggest the existence of hydrogen sulfide. Enrichment of bicarbonate and hydrogen sulfide via $\mathrm{AMO}$ and carbonate precipitation can be represented by the equations (6) and (7),

$$
\begin{gathered}
\mathrm{CH}_{4}+\mathrm{SO}_{4}^{2} \rightarrow \mathrm{HCO}_{3}^{-}+\mathrm{HS}^{-}+\mathrm{H}_{2} \mathrm{O} \\
\mathrm{Ca}^{2+}+\mathrm{HCO}_{3}^{-} \rightarrow \mathrm{CaCO}_{3}+\mathrm{H}^{+}
\end{gathered}
$$

Pyritization involves complex reaction pathways involving $\mathrm{Fe}^{2+}, \mathrm{HS}^{-}, \mathrm{S}^{0}$ and polysulfides [Schoonen, 2004].

[27] Carbon and oxygen stable isotopic compositions of authigenic carbonates (Figure 7) further help constrain their genesis. The sample locations of authigenic carbonates are marked on Figure $4 \mathrm{~d}$. Carbonates show highly depleted carbon isotope composition $\left(\delta^{13} \mathrm{C}\right.$ ranges from -41.3 to $-52.4 \%$ VPDB) typical of biogenic methane derived carbonate precipitation. In contrast, $\delta^{13} \mathrm{C}$ of bivalve shells range from -1.0 to $-1.1 \%$ VPDB suggesting seawater bicarbonate as the carbon source. $\delta^{18} \mathrm{O}$ values are constrained within 3.2 to $5.2 \%$ VPDB similar to the range recorded in methane derived carbonates from several other locations [Kulm and Suess, 1990; Mazzini et al., 2006; Canet et al., 2006; Pierre and Fouquet, 2007; Chen et al., 2007].

[28] Calculated carbonate contents of 10 to $55 \mathrm{vol}$. $\%$ in the carbonate enriched layers cannot result from carbonate precipitation at the present AMO zone. Studies on MSCL based wet bulk density in nearby cores show no density anomaly and only minor abundance of authigenic carbonate in the AMO zone (A. Mazumdar et al., manuscript in preparation, 2009). We attribute the bulk of the authigenic carbonate reported in the present study to paleoseepage close to the sediment-water interface. Cold seep related carbonates are known to form carbonate pavements and mounds at the seafloor [Hovland et al., 1987; Roberts and Aharon, 1994; Kulm and Suess, 1990; Greinert et al., 2001; Judd and Hovland, 2007; H. H. Roberts et al., Seafloor expression of fluid and gas expulsion from deep petroleum systems, continental slope of northern Gulf of Mexico, paper presented at Gulf Coast Section SEPM Foundation 21st Annual Research Conference, Society for Sedimentary Geology, Houston, Texas, 2001]. Recorded carbonate morphological types (Figure 4) in particular the chimneys [Kulm and Suess, 1990; Díazdel-Río et al., 2003; Roberts et al., presented paper, 2001], bioturbation casts and gas flow channels with complex plumbing system indicate AMO related carbonate precipitation close to the sedi- 
ment-water interface. Carbonate-cemented breccias indicate eruption/collapse events due to gas pressure build up under impervious carbonate layers [Hovland et al., 1987; Greinert et al., 2001] or catastrophic methane flux induced by hydrate thawing [Wood et al., 2002; Hovland et al., 2005], whereas carbonate cementation indicate periods of quiescence. The presence of acicular aragonite as isopachous lining along the walls of gas channels and the globular/elongated cavities (Figures 4i, 5a, and 5b) has been observed in some VMCs and chimneys suggesting possible existence of methane hydrate within the globular cavities [Greinert et al., 2001; Canet et al., 2006; Mazzini et al., 2006; Pierre and Fouquet, 2007; G. Bohrmann et al., Gas hydrate carbonates from Hydrate Ridge, Cascadia convergent margin: Indicators of near-seafloor clathrate deposits, paper presented at Fourth International Conference on Gas Hydrates, Japan National Oil Corporation, Yokohama, Japan, 2002].

\subsection{Sediment Fluid Chemistry: Present Zone of AMO}

[29] Profiles of sulfate concentrations, total alkalinity (TA) and methane concentrations (Figure 6a) show a transient and nonsteady state character. The sulfate concentration profile is attributed to the combined effect of rapid sedimentation (gradient I) and anaerobic methane oxidation (gradient III) resulting in nonsteady state character [Hensen et al., 2003]. The nonzero sulfate concentration in gradient IV may be attributed to pyrite oxidation [Bottrel et al., 2000] or incomplete sulfate reduction owing transient state and relatively recent upward migration of methane [Ussler and Paull, 2008]. Sedimentation rates range from 86 to $248.3 \mathrm{~cm} / \mathrm{ka}$ for the first 5-6 $\mathrm{m}$ of the sedimentary package (Figure 8). Under oxic bottom water conditions, sedimentation rate plays an important role in determining the preservation and the pathway of organic matter decomposition and its availability to sulfate reducers [Reeburgh, 1976; Berner, 1978; Stein, 1990; Canfield, 1991, 1994; Tyson, 1995]. High sedimentation rate reduces the oxygen exposure time (OET) which is an important factor affecting preservation of labile components required for sulfate reduction [Hedges and Keil, 1995; Gélinas et al., 2001]. A change in the gradient (II) in sulfate concentration profile may be correlated with the drop in the sedimentation rate to $17.5 \mathrm{~cm} / \mathrm{ka}$ (Figure 6a). A rapid drop in sulfate concentration (gradient III) from $13 \mathrm{mbsf}$ is due to the anaerobic methane oxidation (AMO).
AMO is attributed to a consortium of $\mathrm{CH}_{4}$-oxidizing archaea and sulfate-reducing bacteria [Hinrichs et al., 1999; Boetius et al., 2000; Orphan et al., 2001]. The upward decrease in $\mathrm{C} 1 /(\mathrm{C} 2+\mathrm{C} 3)$ ratios (Table 1) of hydrocarbon gases suggests preferential consumption of methane at and above the AMO accompanied by carbon isotopic enrichment of the residual methane [Whiticar, 1999]. On the basis of the $\mathrm{C} 1 /(\mathrm{C} 2+\mathrm{C} 3)$ ratios and $\delta^{13} \mathrm{C}$ values, a biogenic origin of methane is envisaged [Whiticar, 1999]. The recent methane is possibly advected from greater depth. Presence of methane hydrate within a depth zone of 30-160 mbsf has been reported from this region by Collett et al. [2008, also presented paper, 2008]. The gentle chloride concentration gradient observed at this site (Figure 4b) may be attributed to $\mathrm{Cl}^{-}$exclusion owing to hydrate crystallization (roof effect [Hesse, 2003]).

\subsection{Methane Expulsion Events: Possible Timing and Driving Force}

[30] The presence of methane seep carbonates in association with chemosynthetic clam in the present study suggest that the AMO at this location was close to the sediment-water interface in geological past, in contrast to its present depth. A shallower AMO zone suggests significantly higher methane fluxes in past. In the following paragraphs we attempt to establish the approximate timing of the seep activities and the possible driving forces.

[31] U-Th based dates of carbonate tubules at 16 mbsf range from $\sim 46.2 \pm 3.7$ to $53 \pm 1.6 \mathrm{ka}$. Extrapolated (dotted line in Figure 8) mean calendar age of the host sediment at $16 \mathrm{mbsf}$ is $\sim 58.7 \mathrm{ka}$ B.P. which is close to the upper limit of the U-Th based dates. This puts additional constraint on the younger age limit of the carbonate precipitation/ methane expulsion events. Constraining the carbonate precipitational and clastic sediment depositional ages at $18-20 \mathrm{mbsf}$ is beyond the scope of the present study owing to uncertainty in age determination. Relatively unsystematic ages recorded between 18 and 20 mbsf could be attributed to (1) enhanced sediment mixing owing to bioturbation/sliding associated with rapid sedimentation and (2) uncertainty in age estimation owing to diagenetic alteration of old shells or very low

${ }^{14} \mathrm{C}$ content in foraminifera shells. Additional U-Th age dating is required to bracket the carbonate depositional/methane expulsion events.

[32] The high paleomethane flux in this region was possibly governed by fault/fracture systems as observed in the seismic profile close to the core 
location [Sain and Gupta, 2008; Collett et al., 2008]. Regional seismic lines reported from the $\mathrm{K}-\mathrm{G}$ basin suggest the prevalence of shale tectonics [Bastia, 2006; N. Sinha et al., Spatiotemporal variations and kinematics of shale mobility in Krishna-Godavari basin, India, paper presented at Hedberg Conference, American Association of Petroleum Geologists, Port of Spain, Trinidad and Tobago, 2006]. Numerous shale diapirs, have been inferred from SBP and multibeam bathymetry in the K-G basin offshore [Ramana et al., 2007]. The mound seen in the SBP could have resulted from gravity tectonism driven shale diapirism. Upward movement of the diapir under fluid pressure will result in numerous fault and fractures [Schmuck and Paull, 1993] in the overburden. The main carbonate-rich zone coincides with a possible subsurface depression as observed in the SBP data. The observed carbonate brecciation in association with the subsurface depression indicates possible pockmark formation events at the top of the mud mound. We also recorded minor amounts of methane-derived authigenic carbonates with typical seep signatures above and below the main carbonate horizon suggesting that the major depositional phase was preceded and followed by minor depositional phases, indicating activation and deactivation of the fracture conduits or change in methane pressure at the source.

\section{Conclusions}

[33] A sediment core from the Krishna-Godavari basin identifies the location of a paleo-cold seep as evidenced by authigenic carbonate morphology, the presence of chemosynthetic clam and highly depleted carbon isotopic composition of carbonates. This implies that the AMO was close to the sediment-water interface in past contrast to its present depth. Extrapolation of the calendar age to a depth of 16 mbsf suggest a sediment depositional timing $\sim 58.7$ ka B.P. Whereas U-Th based depositional ages of the authigenic carbonates from this level range from $46.2 \pm 3.7$ and $53.0 \pm 1.6 \mathrm{ka}$ which is close to the sediment depositional age. The present age data helps in constraining the younger age limit of the carbonate deposition/ methane expulsion event.

[34] We attribute the high paleomethane flux to fault and fracture controlled conduits. Shale tectonics driven diapirism possibly resulted in the formation of such fracture/fault zones. This study has unequivocally established occurrence of paleo-cold seepage in the Krishna-Godavari basin, and the possibility of modern seep location in K-G basin needs to be studied in future.

\section{Acknowledgments}

[35] We thank the directors of NIO, NIOT, and NCAOR and the advisor of MOES for supporting this study. H. Leau, head of the Oceanography Department, and P. Sangiardi, in charge of onboard operations of IPEV, are thanked for providing onboard technical support and facilities. Sincere thanks to students of Goa University, IIT Kharagpur, and project scientists of NIO, NIOT, PRL, and NGRI. Arthur Spivack, Walter Borowski, Erwin Suess, and Martin Hovland are thanked for constructive and thorough reviews and suggestions for improvement of the manuscript. This is NIO contribution 4536 .

\section{References}

Bastia, R. (2006), An overview of Indian sedimentary basins with special focus on emerging east coast deepwater frontiers, Leading Edge, 25, 818-829, doi:10.1190/1.2221359.

Bastia, R. (2007), Geologic Settings and Petroleum Systems of India's East Coast Offshore Basins: Concepts and Applications, 204 pp., Eastern Book, Delhi, India.

Bayon, G., C. Pierre, J. Etoubleau, M. Voisset, E. Cauquil, T. Marsset, N. Sultan, E. Le Drezen, and Y. Fouquet (2007), $\mathrm{Sr} / \mathrm{Ca}$ and $\mathrm{Mg} / \mathrm{Ca}$ ratios in Niger Delta sediments: Implications for authigenic carbonate genesis in cold seep environments, Mar. Geol., 241, 93-109, doi:10.1016/ j.margeo.2007.03.007.

Berner, R. A. (1978), Sulfate reduction and the rate of deposition of marine sediments, Earth Planet. Sci. Lett., 37, 492 498, doi:10.1016/0012-821X(78)90065-1.

Boetius, A., K. Ravenschlag, C. Schubert, D. Rickert, F. Widdel, A. Gieseke, R. Amman, B. B. Joergensen, U. Witte, and O. Pfannkuche (2000), A marine microbial consortium apparently mediating anaerobic oxidation of methane, Nature, 407, 623-626, doi:10.1038/35036572.

Bottrel, S., J. Parkes, and R. Raiswell (2000), Deep anoxic pyrite oxidation and stimulation of bacterial activity in marine sediments, J. Conf. Abstr., 5(2), 232.

Campbell, K. A. (2006), Hydrocarbon seep and hydrothermal vent paleoenvironments and paleontology: Past developments and future research directions, Palaeogeogr. Palaeoclimatol. Palaeoecol., 232, 362-407, doi:10.1016/ j.palaeo.2005.06.018.

Campbell, K. A., J. D. Farmer, and D. Des Marais (2002), Ancient hydrocarbon seeps from the Mesozoic convergent margin of California: Carbonate geochemistry, fluids and palaeoenvironments, Geofluids, 2, 63-94, doi:10.1046/ j.1468-8123.2002.00022.x.

Canet, C., R. M. Prol-Ledesma, E. Escobar-Briones, C. MorteraGutierrez, R. Lozano-Santa Cruz, C. Linares, E. Cienfegos, and P. Morales-Puente (2006), Mineralogical and geochemical characterization of hydrocarbon seep sediments from the Gulf of Mexico, Mar. Pet. Geol., 23, 605-619, doi:10.1016/ j.marpetgeo.2006.05.002.

Canfield, D. E. (1991), Sulfate reduction in deep sea sediments, Am. J. Sci., 291, 177-188.

Canfield, D. E. (1994), Factors influencing organic carbon preservation in marine sediments, Chem. Geol., 114, 315 329, doi:10.1016/0009-2541(94)90061-2. 
Chen, J. H., R. L. Edwards, and G. J. Wasserburg (1986) ${ }^{238} \mathrm{U}$, ${ }^{234} \mathrm{U}$ and ${ }^{232} \mathrm{Th}$ in seawater, Earth Planet. Sci. Lett., 80, 241-251, doi:10.1016/0012-821X(86)90108-1.

Chen, Y., R. Matsumoto, C. K. Paull, W. Ussler, III, T. Lorenson, P. Hart, and W. Winters (2007), Methane-derived authigenic carbonates from the northern Gulf of Mexico-MD02 Cruise, J. Geochem. Explor., 95, 1-15, doi:10.1016/j.gexplo. 2007.05.011.

Collett, T., M. Riedel, J. Cochran, R. Boswell, J. Presley, P. Kumar, A. Sathe, A. Sethi, M. Lall, and V. Sibal (2008), Indian National Gas Hydrate Program: Expedition 01, Initial Reports, vol. 1, Dir. Gen. of Hydrocarbon, New Delhi, India.

Delanghe, D., E. Bard, and B. Hamelin (2002), New TIMS constraints on the uranium-238 and uranium-234 in seawaters from the main ocean basins and the Mediterranean Sea, Mar. Chem., 80, 79-93, doi:10.1016/S03044203(02)00100-7.

Díaz-del-Río, V., et al. (2003), Vast fields of hydrocarbonderived carbonate chimneys related to the accretionary wedge/olistostrome of the Gulf of Cadiz, Mar. Geol., 195, 177-200, doi:10.1016/S0025-3227(02)00687-4.

Fairbanks, R. G., R. A. Mortlock, T. Chiu, L. Cao, A. Kaplan, T. P. Guilderson, T. W. Fairbanks, and A. L. Bloom (2005), Marine radiocarbon calibration curve spanning 0 to 50000 years B.P. based on paired ${ }^{230} \mathrm{Th} /{ }^{234} \mathrm{U} /{ }^{238} \mathrm{U}$ and ${ }^{14} \mathrm{C}$ dates on pristine corals, Quat. Sci. Rev., 24, 1781-1796, doi:10.1016/ j.quascirev.2005.04.007.

Gélinas, Y., J. A. Baldock, and J. I. Hedges (2001), Organic carbon composition of marine sediments: Effects of oxygen exposure on oil generation potential, Nature, 294, 145-148.

Gieskes, J. M., T. Gamo, and H. Brumsack (1991), Chemical methods for interstitial water analysis aboard JOIDES Resolution, Tech. Note, 15, Ocean Drill. Program, College Station, Tex.

Goldsmith, J. R., D. L. Graf, and H. C. Heard (1961), Lattice constants of the calcium-magnesium carbonates, $\mathrm{Am}$. Mineral., 46, 453-457.

Greinert, J., G. Bohrmann, and E. Suess (2001), Gas hydrateassociated carbonate and methane-venting at Hydrate Ridge: Classification, distribution and origin of authigenic lithologies, in Natural Gas Hydrate: Occurrence, Distribution and Detection, Geophys. Monogr. Ser., vol. 124, edited by C. K. Paul and W. P. Dillon, pp. 99-113, AGU, Washington, D. C. Han, X., E. Suess, Y. Huang, N. Wu, G. Bohrmann, X. Su, A. Eisenhauer, G. Rehder, and Y. Fang (2008), Jiulong methane reef: Microbial mediation of seep carbonates in the south China Sea, Mar. Geol., 249, 243-256, doi:10.1016/j.margeo.2007.11.012.

Hashimoto, J., S. Ohta, K. Fujikura, Y. Fujiwara, and S. Sukizaki (1995), Life habit of Vesicomyid Clam, Calyptogena soyoae, and hydrogen sulfide concentration in interstitial waters in Sagami Bay, Japan, J. Oceanogr., 51, 341-350, doi:10.1007/ BF02285170.

Hedges, J. I., and R. G. Keil (1995), Sedimentary organic matter preservation: An assessment and speculative synthesis, Mar. Chem., 49, 81-115, doi:10.1016/0304-4203(95)00008-F.

Hensen, C., M. Zabel, K. Pfeifer, T. Schwenk, S. Kasten, N. Riedinger, H. D. Schulz, and A. Boetius (2003), Control of sulfate pore-water profiles by sedimentary events and significance of anaerobic methane for burial of sulfur in marine sediments, Geochim. Cosmochim. Acta, 67, 2631-2647, doi:10.1016/S0016-7037(03)00199-6.

Hesse, R. (2003), Pore water anomalies of submarine gashydrate zones as tool to assess hydrate abundance and distribution in the subsurface: What have we learned in the past decade?, Earth Sci. Rev., 61, 149-179, doi:10.1016/ S0012-8252(02)00117-4.

Hinrichs, K.-U., J. M. Hayes, S. P. Sylva, P. G. Brewer, and E. F. Delong (1999), Methane-consuming archaebacteria in marine sediments, Nature, 398, 802-805, doi:10.1038/ 19751.

Hoffmann, D., J. Prytulak, D. Richards, T. Elliott, C. D. Coath, P. L. Smart, and D. Scholz (2007), Procedures for accurate U and Th isotope measurements by high precision MC-ICPMS, Int. J. Mass Spectrom., 264, 97-109, doi:10.1016/ j.ijms.2007.03.020.

Holbrook, W. S., H. Hoskins, D. Lizarralde, R. A. Stephen, and W. T. Wood (1996), Methane hydrate and free gas on the Blake Ridge from vertical seismic profiling, Science, 273, 1840-1843, doi:10.1126/science.273.5283.1840.

Hovland, M. (2005), Gas hydrates, Encyclopedia of Geology, vol. 4, edited by R. C. Selly, L. R. M. Cocks, and I. R. Plimer, pp. 261-268, Elsevier, Amsterdam.

Hovland, M., M. R. Talbot, H. Qvale, S. Olaussen, and K. Aasberg (1987), Methane-related carbonate cement in the pockmarks of North Sea, J. Sediment. Petrol., 57, 881-892.

Hovland, M., H. Svensen, C. F. Forsberg, H. Johansen, C. Fichler, J. H. Fossa, R. Jonsson, and H. Rueslatten (2005), Complex pockmarks with carbonate-ridges off mid-Norway: Products of sediment degassing, Mar. Geol., 218, 191-206, doi:10.1016/j.margeo.2005.04.005.

Hyndman, R. D., and G. D. Spence (1992), A seismic study of methane hydrate marine bottom simulating reflectors, J. Geophys. Res., 97(B5), 6683-6698.

Ivanovich, M., and R. S. Harmon (1992), Uranium-Series Disequilibrium: Applications to Earth, Marine and Environmental Sciences, Oxford Univ. Press, Oxford, U. K.

Judd, A. G., and M. Hovland (2007), Submarine Fluid Flow, the Impact on Geology, Biology and the Marine Environment, 475 pp., Cambridge Univ. Press, Cambridge, U. K.

Kazutaka, A., and R. G. Jenkins (2007), Eocene drill holes in cold-seep bivalves of Hokkaido, northern Japan, Mar. Ecol., 28, 108-114, doi:10.1111/j.1439-0485.2006.00104.x.

Kigoshi, K. (1971), Alpha-recoil thorium-234: Dissolution into water and the uranium-234/uranium-238 disequilibrium in nature, Science, 173, 47-48, doi:10.1126/science. 173.3991.47.

Kulm, L. D., and E. Suess (1990), Relationship between carbonate deposits and fluid venting, Oregon accretionary prism, J. Geophys. Res., 95, 8899-8915, doi:10.1029/ JB095iB06p08899.

Kulm, L. D., et al. (1986), Oregon subduction zone: Venting, fauna, and carbonates, Science, 231, 561-566, doi:10.1126/ science.231.4738.561.

Kvenvolden, K. (1993), Gas hydrates-Geological perspective and global change, Rev. Geophys., 31, 173-187, doi:10.1029/93RG00268.

Kvenvolden, K. A., and T. D. Lorenson (2001), The global occurrence of natural gas hydrate, in Natural Gas Hydrate: Occurrence, Distribution and Detection, Geophys. Monogr. Ser, vol. 124, edited by C. K. Paul and W. P. Dillon, pp. 318, AGU, Washington, D. C.

Leon, R., L. Somoza, T. Medialdia, F. J. Gonzalez, V. Diazdel-Rio, M. C. Fernandez-Puga, A. Maestro, and M. P. Mata (2007), Sea floor features related to hydrocarbon seeps in deepwater carbonate-mud mounds of the Gulf of Cadiz: From mud flows to carbonate precipitates, Geo Mar. Lett., 27, 237-247, doi:10.1007/s00367-007-0074-2.

Levin, L. A. (2005), Ecology of cold seep sediments: Interactions of fauna with flow, chemistry and microbes, Oceanogr. Mar. Biol. Annu. Rev., 43, 1-46. 
Ludwig, K. R., and D. M. Titterington (1994), Calculation of ${ }^{230} \mathrm{Th} / \mathrm{U}$ isochrons, ages and error, Geochim. Cosmochim. Acta, 58, 5031-5042, doi:10.1016/0016-7037(94)90229-1.

Mazzini, A., M. K. Ivanov, J. Parnell, A. Stadnitskaia, B. T. Cronin, E. Poludetkina, L. Mazurenko, and T. C. E. Weering (2004), Methane-related authigenic carbonates from the Black Sea: Geochemical characterisation and relation to seeping fluids, Mar. Geol., 212, 153-181, doi:10.1016/ j.margeo.2004.08.001.

Mazzini, A., H. Svensen, M. Hovland, and S. Planke (2006), Comparison and implications from strikingly different authigenic carbonates in a Nyegga complex pockmark, G11, Norwegian Seas, Mar. Geol., 231, 89-102, doi:10.1016/ j.margeo.2006.05.012.

Milkov, A. V., G. E. Claypool, Y. J. Lee, G. R. Dickson, W. Xu, and W. S. Borowski (2003), In situ methane concentrations at Hydrate Ridge, offshore Oregon: New constraints on the global gas hydrate inventory from active margins, Geology, 31, 833-836.

Naehr, T. H., P. Eichhubl, V. J. Orphan, M. Hovland, C. K. Paull, W. Ussler, III, T. D. Lorenson, and H. G. Greene (2007), Authigenic carbonate formation at hydrocarbon seeps in continental margin sediments-Examples from active and passive margins, Deep Sea Res., Part II, 54, 1268 1291, doi:10.1016/j.dsr2.2007.04.010.

Orphan, V. J., C. H. House, K. U. Hinrichs, K. D. McKeegan, and E. F. DeLong (2001), Methane-consuming Archaea revealed by directly coupled isotopic and phylogenetic analysis, Science, 293, 484-487, doi:10.1126/science.1061338.

Pierre, C., and Y. Fouquet (2007), Authigenic carbonates from methane seeps of the Congo deep-sea fan, Geo Mar. Lett., 27, 249-257, doi:10.1007/s00367-007-0081-3.

Powell, C. M., S. R. Roots, and J. J. Veevers (1988), Prebreakup continental extension in East Gondwanaland and the early opening of the eastern Indian Ocean, Tectonophysics, 155, 261-283, doi:10.1016/0040-1951(88)90269-7.

Prabhakar, K. N., and P. L. Zutshi (1993), Evolution of southern part of Indian East Coast Basin, J. Geol. Soc. India, 41, $215-230$

Pratson, L. F., and E. P. Laine (1989), The relative importance of gravity-induced versus current-controlled sedimentation during the Quaternary along the Mideast U. S. outer continental margin revealed by $3.5 \mathrm{kHz}$ echo character, Mar. Geol., 89, 87-126, doi:10.1016/0025-3227(89)90029-7.

Ramana, M. V., et al. (1994), Mesozoic anomalies in the Bay of Bengal, Earth Planet. Sci. Lett., 121, 469-475, doi:10.1016/0012-821X(94)90084-1.

Ramana, M. V., T. Ramprasad, and M. Desa (2001), Seafloor spreading magnetic anomalies in the Enderby Basin, East Antarctica, Earth Planet. Sci. Lett., 191, 241-255, doi:10.1016/S0012-821X(01)00413-7.

Ramana, M. V., T. Ramprasad, K. A. Kamesh Raju, and M. Desa (2007), Occurrence of gas hydrates along the continental margins of India, particularly the Krishna-Godavari offshore basin, Int. J. Environ. Stud., 64, 675-693, doi:10.1080/ 00207230701476321

Rao, D. G. (2001), Sedimentation, stratigraphy, and petroleum potential of Krishna-Godavari Basin, east coast of India, AAPG Bull., 85, 1623-1643.

Rao, G. N. (1993), Geology and hydrocarbon prospects of east coast sedimentary basins of India with special reference to Krishna-Godavari basin, J. Geol. Soc. India, 41, 444-454.

Reeburgh, W. S. (1976), Methane consumption in Cariaco Trench waters and sediments, Earth Planet. Sci. Lett., 28, 337-344, doi:10.1016/0012-821X(76)90195-3.
Roberts, H. H., and P. Aharon (1994), Hydrocarbon-derived carbonate buildups of the northern Gulf of Mexico continental slope: A review of submersible investigations, Geo Mar. Lett., 14, 135-148, doi:10.1007/BF01203725.

Sahling, H., D. Rickert, R. W. Lee, P. Linke, and E. Suess (2002), Macrofaunal community structure and sulfide flux at gas hydrate deposits from the Cascadia convergent margin, NE Pacific, Mar. Ecol. Prog. Ser., 231, 121-138, doi:10.3354/meps231121.

Sahling, H., K. Wallmann, A. Dählmann, R. Schmaljohann, and S. Petersen (2005), The physicochemical habitat of Scerolinum $s p$. at Hook Ridge hydrothermal vent, Bransfield Strait, Antarctica, Limnol. Oceanogr., 50, 598-606.

Sahling, H., G. Bohrmann, V. Spiess, J. Bialas, M. Breitzke, M. Ivanov, S. Kasten, S. Krastel, and R. Schneider (2008), Pockmarks in the Northern Congo Fan area, SW Africa: Complex seafloor features shaped by fluid flow, Mar. Geol., 249, 206-225, doi:10.1016/j.margeo.2007.11.010.

Sain, K., and H. Gupta (2008), Gas hydrates: Indian scenario, J. Geol. Soc. India, 72, 299-311.

Sassen, R., I. R. MacDonald, N. L. Guinasso, S. Joye, A. G. Requejo, S. T. Sweet, J. Alcala-Herrera, D. A. DeFreitas, and D. R. Schink (1998), Bacterial methane oxidation in seafloor gas hydrate: Significance to life in extreme environments, Geology, 26, 851-854, doi:10.1130/00917613(1998)026<0851:BMOISF $>2.3 . \mathrm{CO} ; 2$.

Schmuck, E. A., and C. K. Paull (1993), Evidence for gas accumulation associated with diapirism and gas hydrates at the head of the Cape Fear Slide, Geo Mar. Lett., 13, 145 152, doi:10.1007/BF01593187.

Schoonen, A. A. M. (2004), Mechanism of sedimentary pyrite formation, in Sulfur Biogeochemistry: Past and Present, edited by J. P. Amend, K. J. Edwards, and T. W. Lyons, Spec. Pap. Geol. Soc. Am., 379, 117-134.

Sethi, A. K., and N. Ahmad (2006), Gas hydrate a future energy source, Petroview, 1, 5-10.

Shipboard Scientific Party (2000), Explanatory notes, Proc. Ocean Drill. Program Initial Rep., 186, pp. 1-51.

Sibuet, M., and K. Olu (1998), Biogeography, biodiversity and fluid dependence of deep-sea cold-seep communities at active and passive margins, Deep Sea Res., Part II, 45, $517-$ 567, doi:10.1016/S0967-0645(97)00074-X.

Singh, S., T. A. Minshull, and G. D. Spence (1993), Velocity structure of a gas hydrate reflector, Science, 260, 204-207, doi:10.1126/science.260.5105.204.

Sloan, E. D. (1998), Hydrate of Natural Gas, 705 pp., Marcel Dekker, New York.

Stein, R. (1990), Organic carbon content/sedimentation rate relationship and its paleoenvironmental significance for marine sediments, Geo Mar. Lett., 10, 37-44, doi:10.1007/ BF02431020.

Suess, E., et al. (2001), Sea floor methane hydrates at hydrate ridge, Cascadia margin, in Natural Gas Hydrate: Occurrence, Distribution and Detection, Geophys. Monogr. Ser. vol. 124, edited by C. K. Paul and W. P. Dillon, pp. 87-98, AGU, Washington, D. C

Teichert, B. M. A., A. Eisenhauer, G. Bohrmann, A. HaaseSchramm, B. Bock, and P. Linke (2003), U/Th systematics and ages of authigenic carbonates from Hydrate Ridge, Cascadia Margin: Recorders of fluid flow variations, Geochim. Cosmochim. Acta, 67, 3845-3857, doi:10.1016/S00167037(03)00128-5.

Tyson, R. V. (1995), Sedimentary Organic Matter: Organic Facies and Palynofacies, 615 pp., Chapman and Hall, New York. 
Ussler, W., III, and C. K. Paull (2008), Rates of anaerobic oxidation of methane and authigenic carbonate mineralization in methane-rich deep-sea sediments inferred from models and geochemical profiles, Earth Planet. Sci. Lett., 266, 271-287, doi:10.1016/j.epsl.2007.10.056.

Watanabe, Y., S. Nakai, A. Hiruta, R. Matsumoto, and K. Yoshida (2008), U-Th dating of carbonate nodules from methane seeps off Joetsu, Eastern Margin of Japan Sea, Earth
Planet. Sci. Lett., 272, 89-96, doi:10.1016/j.eps1. 2008.04.012.

Whiticar, M. J. (1999), Carbon and hydrogen isotope systematics of bacterial formation and oxidation of methane, Chem Geol., 161, 291-314, doi:10.1016/S0009-2541(99)00092-3. Wood, W. T., J. F. Gettrust, N. R. Chapman, G. D. Spence, and R. D. Hyndman (2002), Decreased stability of methane hydrates in marine sediments owing to phase-boundary roughness, Nature, 420, 656-660, doi:10.1038/nature01263. 